\title{
CASUARIUS GALEATUS.
}

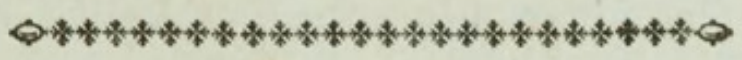

CHARACTER GENERICUS.

Roftrum depreffum, rectum, fubconicum.

Nares ovatæ.

Ala breviffimæ, volatui inutiles.

Femora in parte inferiore denudata.

Pedes tridactyli, digitis omnibus anticis.

Cauda nulla.

$$
\text { Lath. ind. orn. p. } 664 \text {. }
$$

CHARACTER SPECIFICUS, ÉC.

CASUARIUS niger, vertice galeato, collo purpureo-cæruleo, palearibus rubris.

-EMEU.

$$
\text { Will. orn. 105.t. } 25 \text {. }
$$

Struthio CASUARIUS.

$$
\text { Lin. Syft. Nat. p. } 26_{5} \text {. }
$$

CASUARIUS Emeu.

$$
\text { Lath. ind. orn. p. } 664 .
$$

In infulis Indiæ orientalis præcipue confpicitur Cafuarius galeatus, vel ipfi Struthio-camelo magnitudine parum cedens. Cum alarum loco fcapos $\mathrm{O}$ aliquot 
aliquot nudos, breves, acuminatos utrinque gerat, volandi omnino infcius eft. Pennæ totius avis funt valde graciles, laxe plumatæ, et veluti duplices; duæ nempe ab eadem bafi oriuntur. Si cum hac avi comparetur Cafuarius auftralis, quem in hoc opere jam depinximus, facile patebit fpecies inter fe omnino effe diverfas. 


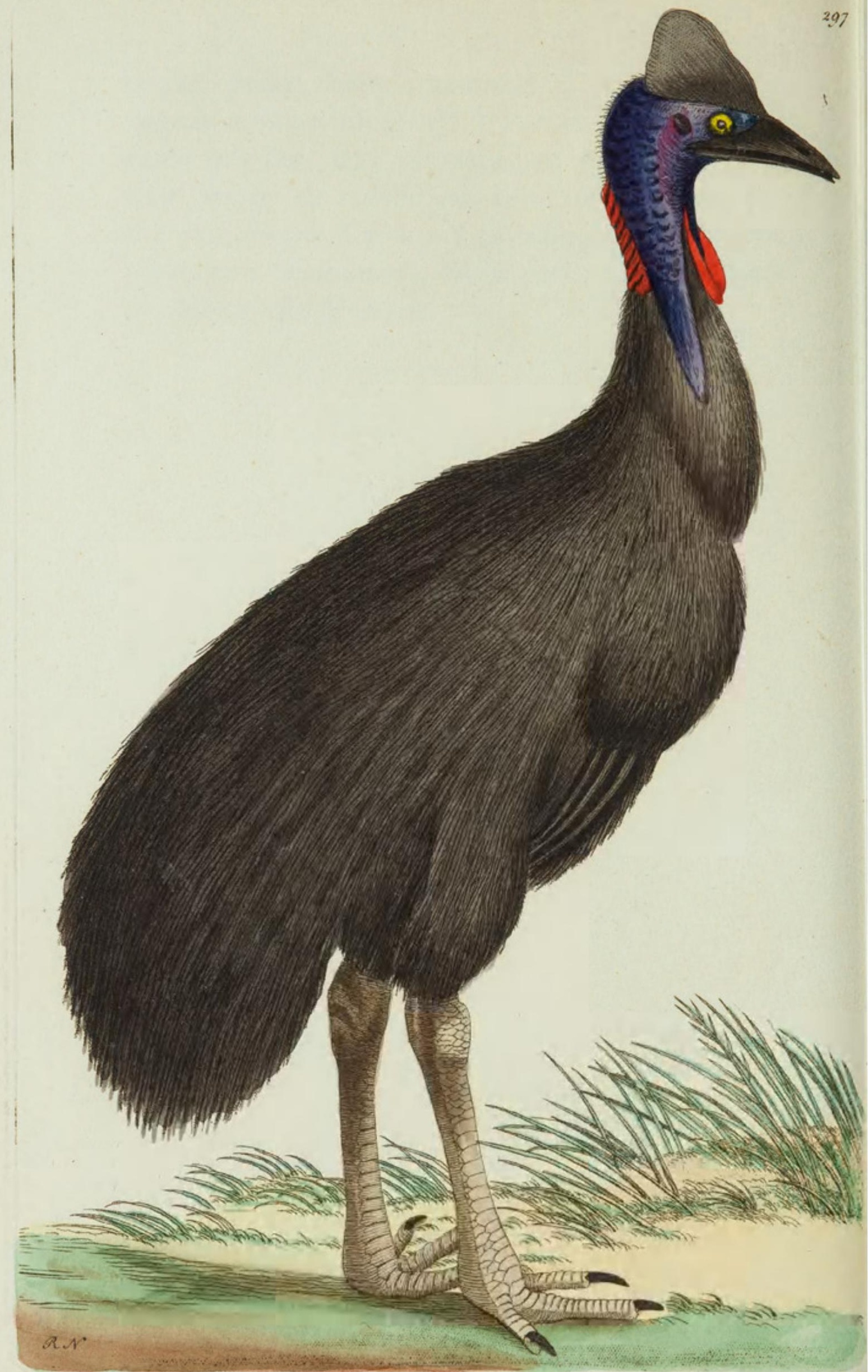


THE

\section{GALEATED CASSOWARY.}

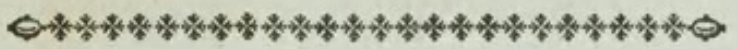

\section{GENERIC CHARACTER.}

Bill depreffed, ftrait, nearly conical. Wings extremely fmall, and unfit for flight.

Feet tridactylous, with all the toes ftanding forwards.

\section{SPECIFIC CHARACTER, E'C.}

Black CASSOWARY, with galeated head, and purple carunculated neck, with red wattles.

The CASSOWARY or EMEU.

$$
\text { Will.orn. p. } 15^{1} \cdot \mathrm{pl} .25 \text {. }
$$

Galeated CASSOWARY.

$$
\text { Lath. Jyn. 3. p. 10. pl. } 7^{2} \text {. }
$$

EMEU.

$$
\text { Robert icon. t. } 4 \text {. }
$$

Le CASOAR.

$$
\begin{aligned}
& \text { Brifs. av. 1. p. 10.pl. 1. f: } 2 . \\
& \text { Buf. ois. 1. p. } 464 \text {. Pl. enl. } 313 .
\end{aligned}
$$

The Caffowary is principally found in the EaftIndian iflands : in fize it is but little inferior to the $\mathrm{O}_{2}$ oftrich: 
oftrich: it is totally deftitute of the power of flight, being furnithed only with a few ftrong, fhort, tharppointed fhafts or naked quills in the place of wings: the feathers throughout the whole bird are of a very flender form, loofely webbed, and double; i. e. two proceeding from the fame bafe or root. The Auftralafian or New Holland Caffowary has been already defcribed in the prefent work, and from a collation of the figure of that bird with the prefent, it will readily appear that the two fpecies are perfestly diftinct from each other. 


\section{$2 \mathrm{BHL}$ Biodiversity Heritage Library}

Shaw, George. 1797. "The Galeated Cassowary, Casuarius galeatus [PI. 297]." The Naturalist's Miscellany 8(XCVI), https://doi.org/10.5962/p.310840.

View This Item Online: https://www.biodiversitylibrary.org/item/276320

DOI: https://doi.org/10.5962/p.310840

Permalink: https://www.biodiversitylibrary.org/partpdf/310840

\section{Holding Institution}

Museums Victoria

\section{Sponsored by}

Atlas of Living Australia

\section{Copyright \& Reuse}

Copyright Status: Public domain. The BHL considers that this work is no longer under copyright protection.

This document was created from content at the Biodiversity Heritage Library, the world's largest open access digital library for biodiversity literature and archives. Visit BHL at https://www.biodiversitylibrary.org. 